\title{
Generator of EEG Delta Rhythms Based on Si Nanowires
}

\author{
K.O. Ostrovska1,**, A.A. Druzhinin², N.S. Liakh-Kaguy2 ${ }^{2}$ I.P. Ostrovskii ${ }^{1,2}$ \\ ${ }^{1}$ Ivan Franko National University of Lviv, 1, Universytetska St., 79000 Lviv, Ukraine \\ ${ }^{2}$ Lviv Polytechnic National University, 12, Bandera St., 79013 Lviv, Ukrarine
}

(Received 04 April 2021; revised manuscript received 03 August 2021; published online 20 August 2021)

\begin{abstract}
The paper deals with the design of a delta rhythm generator of human brain electroencephalogram (EEG) based on investigations of electrophysical characteristics of Si nanowire joints. Si nanowire joints were obtained during their growth by chemical vapour deposition method. The diameter of the Si wires ranges from $100 \mathrm{~nm}$ to $20 \mu \mathrm{m}$. Studies of the $U-I$ characteristics of Si nanowire joints have shown that when a critical value of the current of about $10 \mu \mathrm{A}$ is reached, the generation of voltage fluctuations is observed. The period of oscillations is about $1 \mathrm{~s}$, while their amplitude is $100-120 \mu \mathrm{V}$ that is similar to delta rhythm oscillations in the human brain. Different reasons of the oscillations have been discussed: 1) contact phenomena; 2) existence of strain in the joint junction; 3) existence of non-compensated charges of dangling bonds in the wire surface. A detailed consideration of the proposed reasons has shown that the effect is not associated with contact phenomena, as well as with strain in the joint junction. A possible mechanism of the effect is periodic charge redistribution in the subsurface layer of the wire that leads to compensation of thermo-emf arising due to heating of the joint junction by current. However, this corresponds to the nonequilibrium state of the crystal. The return of the nanowire to equilibrium causes periodic voltage oscillations. The revealed effect allows to elaborate a delta rhythm generator which can be used to treat various diseases (children with autism spectrum disorders, internally displaced persons from antiterrorist operation zone, etc.).
\end{abstract}

Keywords: Silicon nanowires, Elecroencephalogram, Delta rhythm, U-I characteristics, Thermo-emf.

DOI: 10.21272/jnep.13(4).04012

PACS numbers: 78.67.Uh, 81.07.Gf

\section{INTRODUCTION}

A typical electroencephalographic (EEG) signal consists of alpha, beta, theta, gamma, and delta waves, which differ in frequency, as well as amplitude [1]. The frequency of the waves is rather low $(1-100 \mathrm{~Hz})$ and grows in order: $(0.5-4 \mathrm{~Hz})$ delta rhythms, $(4-8 \mathrm{~Hz})$ theta rhythms, (8-12 Hz) alpha rhythms, (13-30 Hz) beta rhythms, and (30-100 Hz) gamma rhythms. As a rule, high-frequency low-amplitude waves are associated with increased activity of the brain. During periods of relaxation, human brain waves become slower, which is accompanied by an increase in the amplitude of alpha waves. Delta rhythms are slow waves of neurocortical human activity, which is dominant during sleeping. Thalamocortical neurons manifest a strong propensity to fall into a silent, hyperpolarized "down-state" after a period of activation giving rise to slow waves (0.5$4.5 \mathrm{~Hz}$ ) in the EEG signal [2]. Besides, delta waves were found in the period of wakefulness during some continuous-attention tasks. The authors of [3] proposed a hypothesis that sustained delta oscillations inhibit interferences that may affect the performance of mental tasks, possibly by modulating the activity of those networks that should be inactive to accomplish the task. The investigations of [4] supported the fascinating hypothesis that brain responses synchronized by slow oscillations restore microwake-like activity patterns that facilitate neuronal interactions. Taking the above information into account, one can conclude that delta rhythms, on the one hand, contribute to the recovery of the body during sleep, and on the other hand, help to slow down certain neural networks when performing mental tasks. Besides, high-amplitude delta rhythms are observed during the period of wakefulness in people with mental disabilities [5] that could be explained by the compensatory abilities of the human body to suppress disordered high-frequency waves.

Until recently, many studies have shown that the main harmful effect on the human body is produced by a high-frequency electromagnetic field. For example, cell phones emitting pulsed high-frequency electromagnetic fields may affect the human brain, which is accompanied by periodic slow-wave activity (1-3 Hz) appeared in the contralateral frontal and temporal areas in children [6]. This wave activity attenuates after 20-30 min. In recent years, more and more information has appeared that serious injuries, for example, Alzheimer disease, depression, etc., can be caused by low-frequency electric and magnetic fields [7]. The authors of [7] showed that in the frequency range from 10 to $25 \mathrm{~Hz}$, the effect of the electromagnetic filed on the population should be limited by the electric field strength in the head tissues, i.e., in the brain, less than $10 \mathrm{mV} / \mathrm{m}$.

On the other hand, the therapeutic effect is known for low-frequency exposure. In particular, the authors of [8] showed that low-frequency stimulation can play a regulatory function by driving neural rhythmic oscillatory activity and influence the thalamocortical dysrhythmia leading to the treatment of fibromyalgia syndrome. In vitro studies [9] demonstrated that tumor-specific frequencies of about $27.12 \mathrm{MHz}$ identified in patients with various forms of cancer are capable of blocking the growth of tumor cells in the tissue. Dissection of the molecular mechanisms accounting for the anti-cancer effects of tumor-specific modulation frequencies is like-

\footnotetext{
*katerynaostrova@gmail.com
} 
ly to lead to the discovery of new cancer treatments.

A novel approach is closely connected with the development of micro- and nanoelectronics. This is primarily due to the possibility of implantation of microchips in the human brain. In particular, Si micro- and nanowires are known to be promising in restoring broken nerve connections [10]. The study shows the possibility of connecting nerves due to the polarization of the wire surface.

The present paper deals with the design of a lowfrequency generator based on Si nanowire. The device is designed to generate electrical signals with the frequency and amplitude of delta rhythms. A simple design in the form of a cross-shaped joint of silicon wires allows to simulate delta rhythms when applied to the human head and to achieve a therapeutic effect.

\section{EXPERIMENT}

Si wires were obtained by crystallization from the gas phase through the liquid phase. The peculiarity of the method is that crystallization of vapors is carried out through an intermediate layer of liquid, the socalled vapour-liquid-solid (VLS) mechanism. A layer or a drop of a solvent is applied to the surface of the substrate, which should form at the crystallization temperature a liquid melt with a substance to be crystallized, have low vapor elasticity and a ratio of interfacial tensions, providing the desired wetting. The substance that crystallizes comes from the gas phase as a result of a transport reaction. The surface of the liquid is the best place for vapor condensation. Gradually, the liquid is supersaturated with a substance coming from the vapor and is released at the crystal-liquid interface. The transfer of matter inside the drop occurs by diffusion. The crystal growth rate is determined not only by the rate of diffusion, but also by the rate of crystallization of the substance. Si wires grow when a layer of liquid breaks up into small droplets. The thickness of these crystals is determined by the diameter of the droplet, which during crystallization is placed on top of a needle in the form of a hemispherical cap (it consists mainly of a metal solvent). This method is convenient because it gives perfect crystals at temperatures relatively low compared to the melting point.

As a rule, conditions are created for the formation of single crystals, which have the greatest prospects for application. Nevertheless, for some tasks, special conditions should be created for the formation of a mesh of wires. To do this, it is necessary to create conditions for the formation of multiple crystal nuclei. Such conditions are achieved due to the pre-treatment of a substrate. Single nuclei are formed on a smooth substrate, while the formation of multiple nuclei predominates on a rough substrate. Taking the above fact into account, the silicon substrate was previously etched in mixtures of hydrofluoric acid (HF) and hydrogen peroxide $\left(\mathrm{H}_{2} \mathrm{O}_{2}\right)$. The temperature of the source zone was $1250^{\circ} \mathrm{C}$, and the temperature of the growth zone was $900{ }^{\circ} \mathrm{C}$. As a result of the growth, various wire joints were obtained (see, for example, Fig. 1). The diameter of crystals was $0.1-20 \mu \mathrm{m}$, the length was $0.001-10 \mathrm{~mm}$. Such joints of InSb wire with micron diameter have application in the thermoelectric converters [11].

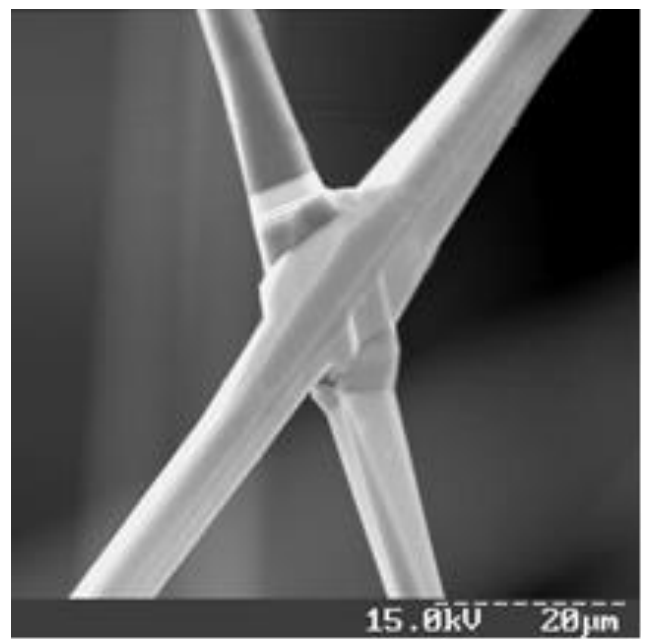

Fig. 1 - "X"-type joint of the Si wire

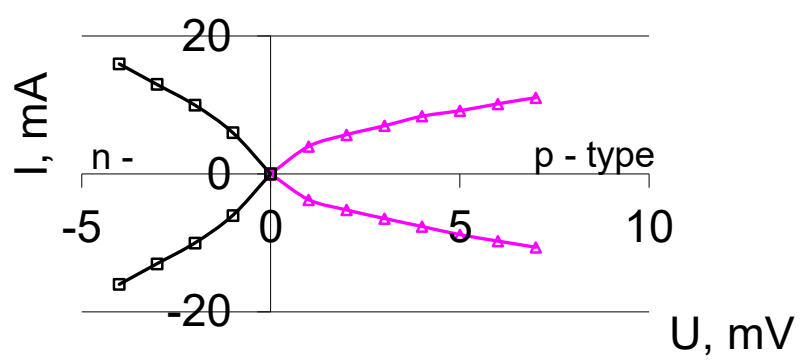

Fig. 2-U-I characteristics of Si "X"-type joints: triangles $p$-type conductivity; squares $-n$-type conductivity

The $n$-type and $p$-type $\mathrm{Si}$ wires were selected as the study objects containing, respectively, antimony and boron with a concentration of $1 \times 10^{18} \mathrm{~cm}^{-3}$. Electrical contacts to Si microcrystals were made of platinum and gold wires with a thickness of $10 \mu \mathrm{m}$, depending on the conductivity type. The described contacts were set by the pulse welding method, which gave the necessary ohmic contacts. Today, there are other alternative technologies that can be used to create metal-semiconductor contacts for submicron wires, in particular, those presented in [12]. Besides, for wires of about 100-200 nm, the contacts were created by using silver paste.

As for electrical parameters, "X"- and "+"-type joints are of great interest (Fig. 1). We used asymmetric "+"type joints of $p$-Si whiskers with resistivity $\rho=0.05 \Omega \cdot \mathrm{cm}$ and $n$-Si whiskers with $\rho=0.1 \Omega \cdot \mathrm{cm}$. The voltage-current characteristics of joints were investigated by applying current to the longitudinal branch and measuring the voltage on the transverse branch.

As a result, we obtain C-type voltage-current characteristics (Fig. 2). As one can see from Fig. 2, $p$-type whisker joints give only positive voltage, while $n$-type ones only negative. The nature of this effect is associated with a thermoelectric phenomenon in the joint. The passage of current through the longitudinal branch leads to heating of the joint junction. Then the thermo-emf arises due to the temperature difference between the junction and the ends of the transverse branch of the joint. The sign of termo-emf depends on the type of charge carriers in semiconductors. Thus, taking into account the sign of the $U-I$ characteristics, one can propose a method for determining the semiconductor type of conductivity. 


\section{DELTA RHYTHMS GENERATOR DESIGN}

Let us consider the $U-I$ characteristics of a joint of wires with submicron diameters (of about $200 \mathrm{~nm}$ ). The way of its measuring is the same as described above. However, one can observe a few differences. The first difference concerns the magnitude of signals. The current applied to the longitudinal branch of the joint is about $10 \mu \mathrm{A}$, while the voltage of the transverse branch reaches hundreds of $\mu \mathrm{V}$. The next difference concerns currents exceeding $10 \mu \mathrm{A}$. When the current reaches the value greater than $10 \mu \mathrm{A}$, spontaneous voltage oscillations occur. The oscillations have a periodic character. One can obtain the period of oscillations that is about $1 \mathrm{~Hz}$. It is curious that the amplitude and period of oscillations are the same as those of delta rhythms of human brain activity. Studies of the $U-I$ characteristics of wire joints of various diameters have shown the size dependence of the period and amplitude of oscillations, which increases by $20 \%$ when the diameter decreases from 200 to $100 \mathrm{~nm}$.

One can suppose a few physical reasons of the effect observed.

1) First of all, these are contact phenomena at the Si wire/gold wire interface. High current passing through the Si-Au junction can damage it and leads to current and, correspondingly, voltage oscillations. In this case, the current should pass through the junction only for a certain period of time, resulting in the maximum value of voltage. The next period of time, when the current is interrupted, should be accompanied by a decrease in the junction temperature and attenuation of voltage. Nevertheless, we did not observe the current interruption during the period of voltage oscillations (of about $1 \mathrm{~s}$ ).

2) The second potential reason for the observed effect concerns the existence of high stress in the joint junction. Additional heating of the junction by current passing through the longitudinal branch of the joint can lead to an abrupt change in the stress value and excite mechanical oscillations. Then mechanical oscillations of the wire can lead to oscillations of the electrical signal, i.e., voltage. The frequency of electrical oscillations should coincide with the frequency of mechanical oscillations. However, mechanical oscillations of the Si nanowire should be rather large (of about $1 \mathrm{GHz}$ ) [13] compared to the frequency observed in our experiment (of about $1 \mathrm{~Hz}$.

3) The existence of mechanical stress in the joint junction can lead to the appearance of piezo-thermo-emf. The author of [14] developed high-performance piezoelectric nanogenerators for self-powered nanosystems. The author of [15] presented a review of the design of a piezoelectric nanogenerator taking into account the mechanical energy processing and the use of piezoelectric nanowires. However, as a rule, the magnitude of piezo-thermo-emf is about $20-30 \%$ of the change in the magnitude of thermo-emf. Therefore, it could not cause the thermo-emf oscillations.

4) The long-term oscillations of thermo-emf can be the result of some process of Si wire surface polarization. Previous investigations of the Si wire interface [10] showed that its surface can contain a positive or negative charge, which is located in a porous shell around the crystalline core of the wire. The existence of a charge in the subsurface layers of wires allows their use for connecting broken nerves [10]. One can suppose that an increase in thermo-emf in the transverse branch of the joint can lead to the charge movement. Thus, redistribution of charges takes place in order to compensate external thermo-emf. Such redistribution duration is about half the period of oscillations, leading to a decrease in the resulting voltage to zero (see the insert in Fig. 3). But the charges are connected with some clusters on the wire surface, which try to return to the equilibrium state. As a result of equilibrium achievement, thermo-emf returns to its previous value. Then the voltage oscillations start again. An increase in the period and amplitude of oscillations by $20 \%$, when the wire diameter decreases from 200 to $100 \mathrm{~nm}$, is associated with a substantial increase in the partial amount of shell in a wire of smaller diameter. As a result, more time is needed to redistribute the charges of dangling bonds leading to period growth. The proposed model can explain the effect, but new questions arise. What is the nature of the clusters in the subsurface layer of wires? The response to this question demands new investigations, in particular, studies of the element content and structure of the wire surface.
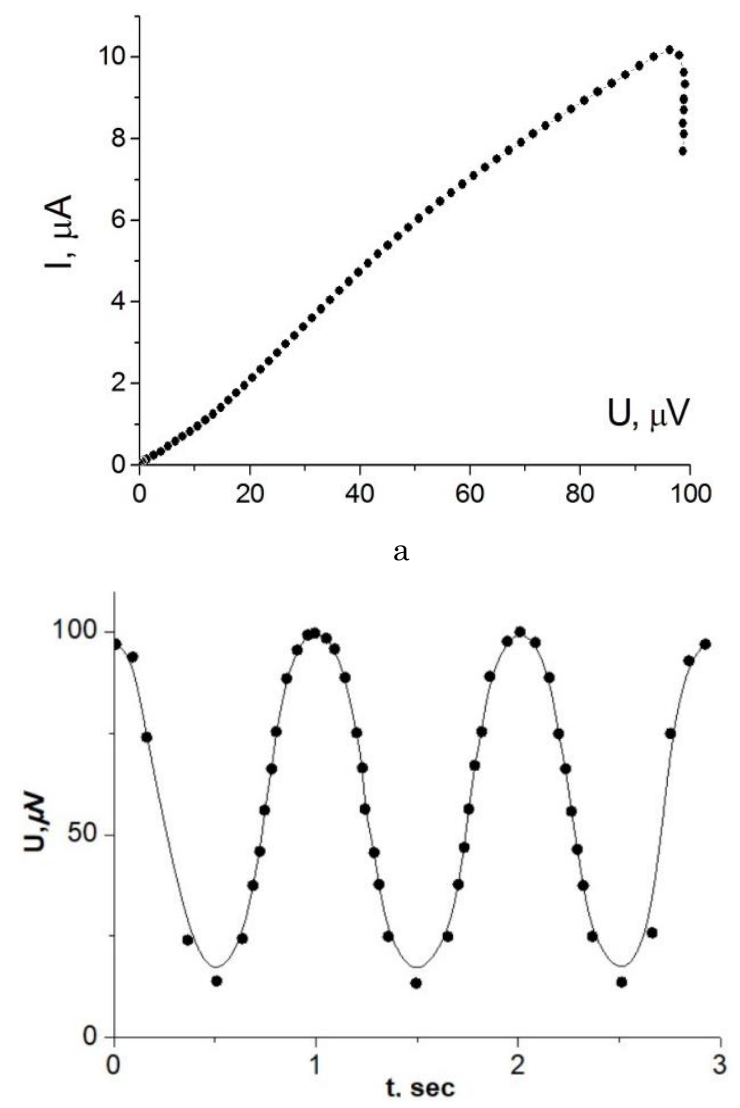

b

Fig. 3-U-I characteristics of the Si nanowire joint (a); voltage oscillations in the Si nanowire joint (b)

\subsection{Application}

In conclusion, let us say about the possible use of the developed generator. As mentioned above, delta rhythms play a regulatory function both for performing 
some mental tasks and suppressing low-amplitude disordered beta and gamma rhythms in children with disabilities. As a rule, the brain generates delta rhythms in children with autism spectrum disorder (ASD) in the wakefulness state. However, in some cases, for example, antisocial behavior in the classroom, hysterics in the workplace, etc., delta rhythms need to be strengthened. This can be realized by interfering intrinsic and external delta rhythms obtained from the generator. Thus, the developed generator can be attached to the patient's head, and at the right time the generation can start. The generator could be used to improve the professional skills of adolescents with ASD [16], calming in case of hysteria the soldiers who returned from the antiterrorist operation zone [17]. These promising applications will become possible after some preliminary experiments on mouse.

\section{CONCLUSIONS}

Studies of the electrophysical characteristics of Si nanowire joints were carried out. Si wires were grown by chemical vapour deposition method and had the diameters ranging from $100 \mathrm{~nm}$ to $20 \mu \mathrm{m}$. The $U-I$ characteristics of Si wire joints were obtained by passing current through the longitudinal branch and measuring the voltage on the transverse branch of the wire joint. The current leads to heating of the joint junction and the appearance of thermo-emf between the junction and the end of the wire due to the temperature difference. It was shown that $n$-type $\mathrm{Si}$ wire gives a negative sign of the thermo-emf, while $p$-type $\mathrm{Si}$ wire gives a positive sign of the thermo-emf. Therefore, it was proposed to use the $U-I$ characteristics of the $\mathrm{Si}$ wire joint to determine the type of conductivity of the material. The measurements of the $U-I$ characteristics of the Si nanowire joint were unexpected. When the current through the nanowire exceeds $10 \mu \mathrm{A}$, the periodic oscillations of voltage arise. The oscillations are similar to those of delta rhythms of the human brain since their period (of about $1 \mathrm{~s}$ ) and amplitude (of about $100 \mu \mathrm{V})$ coincide. The mechanism of the appearance of oscillations is unclear. A few reasons for its explanation were provided. Among them were contact phenomena, existence of mechanical stress in the joint junction, as well as the presence of dangling bonds in the subsurface layers of wires. Analysis of the above reasons has shown that dangling bonds are likely to explain the effect. Si nanowires have a core-shell structure with a crystalline core and a nanoporous shell. The porous shell is a place of non-compensated charge due to the existence of dangling bonds. When the thermo-emf reaches critical values (more than $100 \mu \mathrm{V}$ ), there is an abrupt rearrangement of the nanowire surface, associated with the polarization of the charges, resulting in compensation of the external thermo-emf. Nevertheless, such rearrangement of the nanowire surface is unstable and intrinsic forces try to return the crystal to the equilibrium state. So, the thermo-emf reaches its maximum value again and the oscillations of voltage continue. It is worthy to note that the above explanation should be checked after a comprehensive investigation of the surface structure and its element content by the method of Auger spectroscopy and small angle diffractometry, which requires the following studies.

\section{REFERENCES}

1. W.O. Tatum, R. Ellen, Neurodiagnostic J. 54, 3 (2014).

2. M. Steriade, Neuroscience 137, 1087 (2006).

3. T. Harmony, Front Integr Neurosci. 7, 83 (2013).

4. T.T. Dang-Vu, M. Schabus, M. Desseilles, G. Albouy, M. Boly, A. Darsaud, S. Gais, G. Rauchs, V. Sterpenich, G. Vandewalle, J. Carrier, G. Moonen, E. Balteau, Ch. Degueldre, A. Luxen, Ch. Phillips, P. Maquet, PNAS 105, 15160 (2008).

5. D. Endres, S. Maier, B. Feige, N.A. Posielski, K. Nickel, D. Ebert, A. Riedel, A. Philipsen, E. Perlov, L.T. van Elst, Front. Hum. Neurosci. 11, 66 (2017).

6. A. Kramarenko, U. Tan, Int. J. Neuroscience 113, 1007 (2003).

7. P. Popov, V. Dobref, F. Deliu, P. Burlacu, Naval Academy Scientific Bulletin XIX(1), 256 (2016).

8. L. Naghdi, H. Ahonen, P. Macario, L. Bartel, Pain Res Manag. 20 No 1, e21 (2015).

9. J.W. Zimmerman, H. Jimenez, M.J. Pennison, I. Brezovich, D. Morgan, A. Mudry, F.P. Costa, A. Barbault, B. Pasche, Chin. J. Cancer. 32 No 11, 573 (2013).

10. A. Klimovskaya, N. Vysotskaya, Y. Chaikovsky, A. Korsak, V. Lichodievskiy, I. Ostrovskii, J. Nano Research 39, 214 (2016).

11. A.A. Druzhinin, I.P. Ostrovskii, Yu.M. Khoverko, N.S. LiakhKaguy, J. Nano- Electron. Phys. 12 No 5, 05017 (2020).

12. I.V. Melnyk, Radioelectronics and Communications Systems 56, 592 (2013).

13. A. Pitanti, T. Makkonen, M.F. Colombano, S. Zanotto, L. Vicarelli, M. Cecchini, A. Griol, D. Navarro-Urrios, C. Sotomayor-Torres, A. Martinez, J. Ahopelto, Phys. Rev. Appl. 14, 014054 (2020).

14. W. Wu, Nanotechnology 27, 112503 (2016).

15. W. Xudong, Nano Energy 1 No 1, 13 (2012).

16. K. Ostrovska, I. Ostrovskii, V. Korniat, Special Ugdymas 1 No 38, 61 (2019).

17. L.T. Muzychko, Kh.Ya. Sajko, K. Ostrovska, Psychology and Education 57 No 3, 198 (2020). 


\title{
Генератор дельта ритмів ЕЕГ на основі нанодротів $\mathrm{Si}$
}

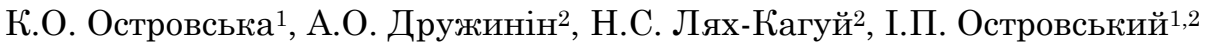

1 Львівський національний університет імені Івана Франка, вул. Університетська, 1, 7900о Львів, Украӥна

${ }^{2}$ Національний університет "Львівська політехніка», вул. С. Бандери, 12, 79013 Львів, Україна

Стаття присвячена розробці генератора дельта ритмів електроенцефалограми (ЕЕГ) людського мозку на основі дослідження електрофізичних характеристик зростків нанодротів Si. Kремнієві мікрота нанодроти вирощували методом хімічного осадження з газової фрази і мали діаметр від 100 нм до 20 мкм. Вольт-амперні характеристики зростків мікро- та нанодротів Si отримували шляхом пропускання струму через поздовжню гілку та вимірювання напруги на поперечній гілщі зростка. Пропускання струму приводить до нагрівання вузла зростка і виникнення термо-ерс за рахунок різниці температур між вузлом і кінцем мікро- та нанодроту. Дослідження вольт-амперних характеристик зростків нанодротів Si показали, що при досягненні критичного значення струму порядку 10 мкА спостерігається поява генерації коливань напруги. Період коливань становить близько 1 с, тоді як їх амплітуда складає 100-120 мкВ, що нагадує коливання дельта-ритму в мозку людини. Обговорювались різні причини коливань: 1) контактні явища; 2) наявність механічного напруження у вузлі зростка; 3) існування нескомпенсованого заряду обірваних зв'язків у приповерхневих шарах нанодротів. Детальний розгляд запропонованих причин показав, що ефект не пов'язаний з контактними явищами, а також із наявністю механічних напружень у вузлі зростка нанодротів. Можливим механізмом виявленого ефекту е стрибкоподібний перерозподіл заряду в приповерхневих шарах нанодроту, що призводить до компенсації наведеної термо-ерс. Однак, це відповідає нерівноважному стану кристалу. Повернення нанодроту до рівноважного стану зумовлює періодичні коливання напруги. Виявлений едект дозволив розробити генератор дельта-ритмів, який може бути використаний для лікування різних захворювань (діти з розладами спектру аутизму, внутрішньо переміщені особи із зони антитерористичної операції тощо).

Ключові слова: Нанодроти кремнію, Електроенцефалограма, Дельта ритм, Вольт-амперні характеристики, Термо-ерс. 